\title{
Analysis of Max Morden's Identity Crisis and Self-construction in The Sea Based on Psychoanalytic Theory
}

\author{
Lei Guo ${ }^{1}$, Zhen Ge ${ }^{2 *}$ \\ ${ }^{1}$ The Associate Professor of North China Electric Power University in China \\ ${ }^{2}$ The Post-Graduate Student Majoring in English Language and Literature of North China Electric Power University in China
}

DOI: $10.36348 /$ sijll.2020.v03i05.004

| Received: 16.05.2020 | Accepted: 26.05.2020 | Published: 28.05.2020

*Corresponding author: Zhen Ge

\section{Abstract}

The Sea, one of the most representative works about identity crisis and self-construction, shows Max Morden's absence of life and struggling in memory. Based on the Psychoanalytic Theory of Literature, this paper aims to study the main character Max Morden's self-identity crisis and come up with feasible ways to solve the problem. By analyzing Max Morden's identity crisis and self-construction in The Sea, it reveals the author John Banville's thinking of value and the meaning of life. It will help people understand the self-identity crisis, its cause, and how to solve it in modern society.

Keywords: The Sea, Psychoanalytic Theory, identity crisis, self-construction, Max Morden.

Copyright @ 2020: This is an open-access article distributed under the terms of the Creative Commons Attribution license which permits unrestricted use, distribution, and reproduction in any medium for non-commercial use (NonCommercial, or CC-BY-NC) provided the original author and source are credited.

\section{INTRODUCTION}

The Sea is a famous work written by Ireland writer John Banville, which illustrates Max Morden's journey to find his self-identity. Art historian Max Morden is an old man who has a wife and a daughter. One day, because of his wife's death he has returned to his boyhood seaside village to escape both the new sorrows of life and the torments of memories. Max Morden meets the Grace family at the seaside and becomes best friends with them. He thinks they are mysterious as if they from another world. Later, he participates in their life and he is influenced a whole life by their story. This story adopts the technique of time and space transformation so that the present and the past are very ingeniously entangled together. In the story, a series of events in the distant past have left Max Morden with an unforgettable pain, his wife's death also brings him unsolved wounds. The painful experiences not only create a unique painful story but also express Max Morden's self-identity crisis and his process of reconstruction.

\section{Psychoanalytic Theory of Literature}

When we look at the world through a psychoanalytic lens, we see that is it comprised of individual human beings, each with psychological history that begins in child hood experiecnesin the family and each with patterns of adolescent and adult behavior that are the direct result of that early experience [1]. The psychoanalytic theory of literature includes two representative founders Sigmund Freud and Jacques Lacan. From Sigmund Freud's psychoanalytic theory, we learned about Superego, id, and Ego. The social values and taboos that we internalize (consciously or unconsciously) and experience as our sense of right and wrong. The superego is in direct opposition to the id, the psychological reservoir of our instincts, and our libido, or sexual energy. The id is devoted solely to the gratification of prohibited desires of all kinds - the desire for power, for sex, for amusement, for foodwithout an eye to consequences. The ego, or the conscious self that experiences the external world through the senses, plays a referee between the id and superego, and all three are defined by their relationships: none acts independently of the others and a change in one always involves changes in the other two. Unconsciousness is a word of this stage. Besides, unconsciousness is exposed to the external environment, and then reflects the rational content of the object. Unconsciousness is a real mental reality [2]. It illustrates the mind-changing of a human being including choice and decision.

Identity is an important concept in the psychoanalytic theory of literature. It related to the Lacanian psychoanalytic theory. Moreover, with the classical psychoanalytic theory of literature we've stated, there was a French psychoanalyst, Jacques Lacan, who came up with three orders: The Imaginary Order, the Symbolic Order, and the Real Order. 
Besides, Jacques Lacan also stated the Mirror Stage of infants: the infants don't differentiate themselves from the environment and don't know what parts of their own body are. They cannot recognize the whole world. From the sixth months to eighth months, the Mirror Stage appears. They become to recognize themselves from the mirror but they still can't differentiate themselves in the mirror. If you take the mirror, they will recognize themselves. When they grew up to the eighth month, they begin to distinguish themselves from others and cultivate the ability to control themselves. Their self-identities begin to develop. Lacan thinks that when the post-mirror stage, the infant can distinguish their difference from their parents and the others. The earlier mirror image is the imaginary object. Using this object, the infants can build their selfawareness and self-identities. Lacan refers to this lost object of desire as "object small a", with the letter a standing for autre, the French word for others. Objet petit is the "little other" that belongs only to me, that influence only me. As we'll see, the Other with a capital $\mathrm{O}$, in contrast, influences everyone. Everyone always seeks the Other for their self-identities.

In The Sea, Max Morden's loss and lack for his self-identity is the main part and people can learn that John Banville pays more attention to this point to solve the self-identity crisis in the modern society. From this novel, Max Morden's psychological activities show his uncertainty of self-identity and his identity dilemma. He wants to seek his real self-identity but he is controlled by social rules and other definitions. This paper mainly studies the identity crisis of the male character of John Banville's work The Sea and the feasible solution for this problem.

\section{Max Morden's Identity Crisis}

From the psychoanalytic theory of literature, every man always needs to seek his self-identity and choose the Other. Everyone's id is controlled by the superego and ego, so everyone is eager to find out the true self. In this process, they will meet many challenges and troubles. They need to have the correct attitude facing the whole life to solve the identity dilemma. we've learned that the family environment is an indispensable factor in the formation of self-identity. The main character Max Morden's mother and father both are irresponsible for his growth. Due to his father and mother often quarrel with each other, Max Morden appears psychological deformity, lost confidence, etc. Nevertheless, the disharmonic family relationship exerts a great influence on Max Morden.

His father leaves him early to England and his mother always screams at him without reason. Max Morden is innocent and doesn't have the ability to revolt the fate. Max Morden can't distinguish the world and what's wrong and right. Like the infants in the mirror stage, he can't differentiate himself from his mother and the environment. His mother once was his most family but she didn't give him enough love and care. When he meets the family Grace, his life has been changed greatly in mind and his later life. Because he lacks his maternal love, he begins to seek something or someone to replace his loss part. For Max Morden, the family Grace is mysterious and unusual. His skin was so deeply tanned by the sun it had a purplish sheen. Even his feet, I noticed, were brown on the insteps; most fathers in my experience were fish-belly white below the collar-line [3]. Max Morden doesn't have many memories for his father so his impression of the image of the father is his imagination. From his perspective, the master of the family Grace is unusual and different from the other's father. Another evidence is that his psychological activity for the master's wintry whistling and he even wants to turn into him due to his father used to whistle like that. As we can see, Max Morden lacks not only his maternal love but also his father's love. He is eager to have a true love for himself. Due to this loss and lack, he can't recognize himself accurately. He often wants to follow other's steps and loss himself. The disharmonic family relationship causes Max Morden's loss of his selfidentity. His memory is a mirror for his identity crisis [4].

From the above, Max Morden's identity crisis origins his childhood experience and the depression of the social regulations. He loses himself in a colorful world. He supposed to be anybody else and makes friends with others to recognize himself. The impact of the age characteristics and external objective factors brings children various emotional obstruction and thus affects their health both physically and mentally.

\section{Max Morden's Self-construction}

From the psychoanalytic theory of literature, the id is eager for the power, for sex, for amusement, for good. It consists of the desires regulated or forbidden by social regulation or convention. Superego is the perfect state for a person and it is difficult to achieve it. In the story, Max Morden was controlled by social regulation and convention, he couldn't fight for himself and he only could follow other's bodies to enrich his identity. Besides, some scholars think memory is an important approach for constructing and deconstructing identity [5]. From his experience, it illustrates two positives of self-construction to solve his self-identity.

The first positive period of Max Morden's construction is about his obsession with Mrs. Grace. Max Morden's memory for Mrs. Grace is so clear because of her uniqueness. He remembers her voice, her form, and her behaviors. From the story, the readers can learn that Max Morden lacks maternal love and his mother always scolds him without reason and excuse. $\mathrm{He}$ is long for normal family life and warmth mother to love him. In the psychoanalytic theory of literature, the Oedipus complex is often appearing on the boy who 
lacks maternal love. Max Morden's behavior shows the influence of the Oedipus complex for a boy. He is drawn into Mrs. Grace's character and mother's elegance. In his imagination, the task for the role of the mother is to take care of their children and husband. In their leisure time, they can do what they want. He imagines Mrs. Grace was his lover and this way to some extent helped him to build an identity. He imagines if she were his mother, his life would be changed greatly. However, Chole Grace and their tutor's relationship destroys his cognition. Such a happy family! It is a feint. Gradually he knows his love is not right and he knows what the right love is. The first construction of identity is failed.

The second positive period construction is about Chole Grace. In the novel, the author uses the elegant language showing Max Morden's psychological activity. "I first saw her, Chloe Grace, on the beach. It was a bright, wind-worried day and the Graces were settled in a shallow recess scooped into the dunes by wind and tides to which their somewhat raffish presence lent a suggestion of the proscenium [3]." Max Morden thinks Chloe Grace is his real love. They always play with each other. Max Morden wants to learn how to orientate himself from Chole Grace. However, Chole Grace has absolute dominance in this relationship with Max Morden. Besides, the relationship between Chole Grace's brother is strange. The Grace family is not harmonious. Max Morden is confused about his identity again. One day, Rose finds that Chole is necking with Max Morden. They quarrel with each other. Finally, Chole Grace and his brother commit suicide in The Sea. Max Morden doesn't know why the twins choose this way to terminate their lives. The second construction is also failed and leaves great trauma on Max Morden.

The third positive period of construction is with his wife Anna. In Identity Crisis and Ethical Tragedy in The Sea, based on ethics and the Other method, Guo Jingjing [6] considers that family is an indispensable contributor to Max's tragedy and discusses the important meaning of family. In the novel, the description of his wife Anna is in contrast with Max Morden. Facing the seriousness, Anna is positive and optimistic. She has the spirit of revolt and is not afraid of the result of destiny. Max Morden doesn't know what his role is in society, but he finds the selfpositioning from his wife Anna. Like the infants can distinguish himself from the actual mirror, Max Morden recognizes his self-identity. He tries to be a good husband and a father, but due to his miserable childhood experience, he can't do well. When his wife died, he loses his life orientation and his self-identity. Max Morden cannot receive this result so he returns to the apartment where he meets the family Grace. In brief, Max Morden reflects on his traumatic experience and knows his identity crisis. He begins to explore ways to solve his psychological problem.
In The Ego and the Id, Freud says that "Thus we obtain our concept of the conscious from the theory of repression. The repressed is the prototype of the unconscious for us" [7]. Max Morden always repressed his identity crisis and he thinks the traumas are less important. Max Morden's miserable family and poor economic conditions make him more mid and overcautious. He always seeks his true love, in other words, which means that it represents his self-identity. Because of his failed self-construction, he chooses to return to The Sea to recapture the lost innocence of youth. Finally, he finds all the trusts are an illusion and he lost self-identity again.

From the psychoanalytic theory of literature, the child develops a sense of self as if it had identified with the whole image of itself that can be seen reflected in a mirror. The story invokes Max Morden's reflection of his self-identity. He is suspicious of his identity. For Max Morden, the memory not only means the first half of his life but means the process of reconstruction and understand himself of the past. His memory is a mirror. $\mathrm{He}$ is long for the family Grace, but now he recognizes that there are hatred and incest behind the beautiful love and the happy family. His daughter tells him the truth and lets him know what is most important in life. His experience origins at The Sea and ends at The Sea, and it shows the original state of Max Morden. The Sea symbolizes vitality and mystery that connects with the human being's fate. His id wants to break through the troubles that social regulations and conventions. According to his endeavor, he knows the significance and the value of life.

\section{CONCLUSION}

Based on psychoanalytic theory, this paper studies the reasons for his self-identity crisis and explores the process of his identity construction. A series of events affect Max Morden's identity. Max Morden often dreams of his traumatic experience. It includes latent content and manifest content. The dream symbolizes the unconscious traumas [8]. With his wife's death, he gradually knows the meaning of identity and knows his identity problem. According to this story, it will help people understand the selfidentity crisis and its cause and how to solve the problem in modern society. Everyone needs to face their identity problem actively and explores ways to solve it. The psychoanalytic theory provides a new angle for those people who meet identity problems and needs further study.

\section{REFERENCES}

1. Tyson, L. (2006). Critical Theory Today [M]. Routledge, 12.

2. O'connell, M. J., Bachilo, S. M., Huffman, C. B., Moore, V. C., Strano, M. S., Haroz, E. H., ... \& Ma, J. (2002). Band gap fluorescence from individual single-walled carbon nanotubes. Science, 297(5581), 593-596. 
3. Banville, J. (2006). The Sea [M]. New York: Vintage, 6-7.

4. Zhao, G., Li, J., Ren, X., Chen, C., \& Wang, X. (2011). Few-layered graphene oxide nanosheets as superior sorbents for heavy metal ion pollution management. Environmental science \& technology, 45(24), 10454-10462.

5. Zheng, X., Chen, B., Dai, J., Fang, Y., Bai, Y., Lin, Y., ... \& Huang, J. (2017). Defect passivation in hybrid perovskite solar cells using quaternary ammonium halide anions and cations. Nature
Energy, 2(7), 1-9.

6. Guo, J., \& Yang, C. (2015). Highly stabilized phase-shifted fiber Bragg grating sensing system for ultrasonic detection. IEEE Photonics Technology Letters, 27(8), 848-851.

7. Freud, S. (1962). The Ego and the Id [M]. New York: W.W. Norton \& Co., 5.1

8. Wang, J., Duncan, D., Shi, Z., \& Zhang, B. (2013). WEB-based gene set analysis toolkit (WebGestalt): update 2013. Nucleic acids research, 41(W1), W77-W83. 